\title{
INOVASI PERAN PEMERINTAH DESA DALAM KEBIJAKAN PARIWISATA DI KOTA BATU
}

\author{
Akhmad Amirudin \\ Program Studi Ilmu Administrasi Publik, Fakultas Ilmu Administrasi, Universitas Brawijaya, \\ akhmadamirudin@gmail.com
}

\begin{abstract}
Abstrak
Penelitian ini mengkaji terkait dengan inovasi peran perangkat desa dalam kebijakan pariwisata di Kota Batu, Kota Batu merupakan salah satu Kota di Indonesia yang pertumbuhan perekonomiannya didominasi oleh sektor pariwisata. Pertumbuhan ekonomi selama tahun 2012-2016 perekonomian Kota Batu telah menunjukkan tanda peningkatan dengan rata-rata mencapai 6,95 persen akan tetapi angka kemiskinan belum menunjukkan penurunan yang signifkan dengan jumlah lebih dari 9.000 jiwa sejak 2013 hingga 2016 dan rasio gini pada tahun 2015 tercatat 0,36 poin atau naik dari angka tahun 2013 yaitu 0,31 poin.Hal ini menunjukkan bahwa pertumbuhan sektor pariwisata belum mampu dirasakan oleh seluruh masyarakat. hal ini terjadi dikarenakan sektor pariwisata masih didominasi oleh investor besar dengan membangun pariwisata artificial (buatan) yang minim melibatkan masyarakat, oleh sebab itu pemerintah Kota Batu mengembangkan pendekatan baru dengan mengoptimalkan peran pemerintah desa dalam mengembangan kebijakan dewi (desa wisata) dan membentuk pokdarwis (kelompok sadar wisata). Penelitian ini menggunakan pendekatan kualitatif, jenis penelitian studi kasus dan analisis model interaktif dari Miles, Huberman dan Saldana. Hasil analisis menunjukkan, bahwa inovasi peran perangkat desa dalam mengembangkan destinasi wisata baru yang berbasis masyarakat serta kolaborasi dengan pokdarwis telah memberikan bentuk baru dalam kebijakan pariwisata di Kota Batu, desa-desa wisata yang dikembangkan pada tingkat desa lebih berhasil memberikan pengaruh positif terhadap kesejahteraan masyarakat serta mampu melibatkan masyarakat secara masif.
\end{abstract}

Kata Kunci: Kebijakan, Pariwisata, Pemerintah Desa.

\begin{abstract}
This research examine the innovation of village government roles in tourism policy in Batu Municipality, Batu Municipality is one of the cities in Indonesia whose economic growth is dominated by the tourism sector. Economic growth during 2012-2016 Batu City's economy has shown a marked increase with an average of 6.95 percent but the poverty rate has not shown a significant decline with the number of more than 9,000 people since 2013 to 2016 and the gini ratio in 2015 was recorded at 0,36 points or up from the 2013 figure of 0.31 points. This indicates that the growth of the tourism sector has not been able to be felt by the entire community. this happens because the tourism sector is still dominated by large investors by building artificial tourism (artificial) which involves minimal society, therefore the city government of Batu develop a new approach by optimizing the role of village government in developing the policy village tourism and form of pokdarwis (kelompok sadar wisata (group of tourism awareness)). This research uses qualitative approach, case study research and interactive model analysis from Miles, Huberman and Saldana. The result of the analysis shows that the innovation of the role of village apparatus in developing the new community based tourism destination and the collaboration with pokdarwis has given a new form in tourism policy in Batu Town, the tourist villages developed at the village level are more successful in giving positive influence to the people's welfare as well able to involve massively society.
\end{abstract}

Keywords: Policy, Tourism, Village Government.

\section{PENDAHULUAN}

Kebijakan publik dibuat oleh pembuat kebijakan untuk mengatasi masalah yang dihadapi. Masalah tersebut berupa masalah sosial, ekonomi, dan sektor lain yang perlu perhatian dan penyelesaian. Kebijakan akan mampu menyelesaikan masalah apabila diterapkan dengan implementasi yang baik. Nugroho (2014) berpendapat bahwa "kebijakan yang baik atau berhasil $60 \%$ dinilai berdasarkan implementasinya". Selain itu, untuk mengatasi masalah ekonomi, pemerintah selaku pembuat kebijakan akan membuat kebijakan ekonomi. Kebijakan pembangunan ekonomi sendiri, saat ini terus berkembang dan memiliki berbagai jenis pendekatan.Pendekatan yang sesuai dengan pembangunan di daerah adalah konsep pengembangan ekonomi lokal yang dipadukan dengan desentralisasi daerah sehingga pemerintah daerah memiliki kewenangan yang lebih luas terhadap pembangunan dan pengembangan daerah 
Kota Batu adalah salah satu Kota Pariwisata yang memiliki pertumbuhan perekonomian yang cukup pesat di Indonesia. Selama tahun 2012-2016 perekonomian Kota Batu telah menunjukkan tanda peningkatan. Hal ini terlihat dari pertumbuhan ekonominya yang menunjukan arah positif dan terus meningkat. Pertumbuhan ekonomi Kota Batu dari tahun 2012 sampai dengan 2016 secara rata-rata mencapai 6,95 persen, dengan masing-masing pertumbuhan sebesar 7,26 persen pada tahun 2012; 7,29 persen pada tahun $2013 ; 6,90$ persen pada tahun 2014 ; dan 6,69 persen pada tahun 2015 serta 6,61 persen pada tahun 2016. Pertumbuhan tertinggi terjadi pada tahun 2013 yakni sebesar 7,29 persen, sebaliknya yang terendah terjadi pada tahun 2016 sebesar 6,61 persen. Akan tetapi angka kemiskinan pada tahun 2013 tercatat sebesar 9.400 jiwa atau 4,77 persen, tahun 2014 turun menjadi 9.100 jiwa atau 4,59 persen; dan tahun 2015 menjadi 9.430 jiwa atau 4,71 persen serta tahun 2016 turun menjadi 9.050 jiwa atau sebesar 4,48 persen. Selanjutnya tingkat Pengangguran Terbuka mengalami angka fluktuatif. Pada tahun 2015 tercatat 4,29\% atau naik dari angka tahun 2013 yaitu 2,32 \%. Kondisi ini perlu menjadi percermatan kita bersama untuk melihat data fenomena ini, sekaligus mencari solusi secara cepat dan tepat. Serta angka indeks gini pada 2015 yang menunjukkan pertumbuhan ekonomi yang sangat baik namun juga menjadi penanda ketimpangan pendapatan yang semakin besar di masyarakat Kota Batu. Data menunjukkan tahun 2014 gini ratio menunjukkan angka 0.29 dan tahun 2015 menunjukkan angka 0.36, maka pada tahun 2015 peningkatan angka gini ratio terbesar dalam kurun waktu 6 tahun terakhir. Hal ini tentu menjadi early warning bagi Pemerintah Kota Batu untuk mengkaji ulang kebijakan pariwisata. Oleh sebab itu penting untuk meneliti implementasi kebijakan pariwisata di Kota Batu dalam kotribusinya pada ekonomi lokal masyarakat.

Kota Batu telah menunjukkan tanda peningkatan dengan rata-rata mencapai 6,95 persen akan tetapi angka kemiskinan belum menunjukkan penurunan yang signifkan dengan jumlah lebih dari 9.000 jiwa sejak 2013 hingga 2016 dan rasio gini pada tahun 2015 tercatat 0,36 poin atau naik dari angka tahun 2013 yaitu 0,31 poin. Hal ini menunjukkan bahwa pertumbuhan sektor pariwisata belum mampu dirasakan oleh seluruh masyarakat. hal ini terjadi dikarenakan sektor pariwisata masih didominasi oleh investor besar dengan membangun pariwisata artificial (buatan) yang minim melibatkan masyarakat, oleh sebab itu pemerintah Kota Batu mengembangkan pendekatan baru dengan mengoptimalkan peran pemerintah desa dalam mengembangan kebijakan dewi (desa wisata) dan membentuk pokdarwis (kelompok sadar wisata)
Berdasarkan uraian tersebut terdapat permasalahan bahwa sektor jasa hotel memiliki kontribusi terhadap perekonomian Kota Batu namun apakah sektor tersebut memberikan dampak bagi masyarakat dan mampu mengurangi kesenjangan ekonomi masyarakat maka kebijakan pariwisata harus diarahkan pada pemerataan pendapatan bagi seluruh masyarakat Kota Batu, untuk itu peneliti menetapkan judul penelitian "Implementasi Kebijakan Undang-Undang Nomor 9 Tahun 2010 Tentang Kepariwisataan Di Kota Batu Dalam Pengembangan Ekonoim Lokal" dan dapat disusun rumusan masalah sebagai berikut: 1) Bagaimanakah implementasi kebijakan pariwisata di Kota Batu? Dan 2) Bagaimana Peran Pemerintah Desa dalam Kebijakan Pariwisata?

\section{METODE}

Metode penelitian ini adalah kualitatif, dimana peneliti dalam mengumpulkan data bersifat emic, yaitu berdasarkan pandangan sumber data, bukan pandangan peneliti (Sugiyono, 2015: 6). Jenis penelitian ini adalah studi kasus. Arikunto (2006) mengemukakan bahwa "metode studi kasus sebagai salah satu jenis pendekatan deskriptif, penelitian yang dilakukan secara insentif terperinci dan mendalam terhadap suatu organisme (individu), lembaga atau gejala tertentu dengan daerah atau subyek yang sempit". Data dikumpulkan dengan wawancara, observasi dan dokumentasi. Penelitian studi kasus ini berpedoman pada teori yang sudah ada. Posisi pemanfaatan teori yang telah ada dimaksudkan untuk menentukan arah dan fokus penelitian.

Teknik analisis data penelitian ini adalah model interaktif Miles, Huberman dan Saldana (2014), "kegiatan analisis data terdiri dari tiga alur kegiatan yang terjadi secara bersamaan yaitu: kondensasi data, penyajian data dan penarikan kesimpulan/verifikasi”. Data yang ditemukan diuji kebenarannya dengan menganalisis dan mengklarifikasinya dengan model implementasi model George C Edward III, top down, enforced mechanism dan market mechanism. Kemudian menguji keabsahannya dengan sumber di lapangan dan metode, maupun diskusi. Kesimpulan diinterpretasikan dari verifikasi yang disesuaikan dengan data dan kajian yang diperoleh selama penelitian.

\section{HASIL DAN PEMBAHASAN}

\section{Implementasi Kebijakan Pariwisata Di Kota Batu}

\section{Komunikasi}

Komunikasi merupakan salah satu variabel yang mempengaruhi keberhasilan implementasi kebijakan. Kebijakan harus dikomunikasikan kepada pelaksana, pihak yang terlibat dan sasaran, sehingga tujuan dan 
sasaran kebijakan bisa tercapai. Menurut Edward III komunikasi dalam implementasi kebijakan memiliki 3 (tiga) dimensi. Pertama dimensi transisi, dimensi ini menghendaki bahwa kebijakan harus disampaikan kepada pelaksana kebijakan, selain itu juga harus disampaikan kepada pihak lain yang berkepentingan dan kelompok sasaran dari kebijakan. Dalam proses implementasi kebijakan Undang-Undang nomor 10 Tahun 2009 tentang Kepariwisataan di Kota Batu, Dinas Pariwisata melakukan komunikasi di pegawai internal dinas yang selaku pelaksana kebijakan. Komunikasi di internal dinas dilakukan melalui rapat di setiap hari senin, dan juga melalui rapat di setiap bidang. Selain itu komunikasi juga dilakukan melalui group media sosial whatsapps, terdapat beberapa group yang dibuat untuk komunikasi antar pelaksana sepertu group aparatur sipil negara Kota Batu group eselon 2, group eselon 3, group per Satuan Kerja Perangkat Daerah, group struktural dalam Dinas Pariwisata, dan group bidang di Dinas Pariwisata, dimana di group tersebut digunakan untuk menyampaikan informasi dan berkoordinasi dengan pelaksana lainnya. Komunikasi berkaitan dengan implementasi kebijakan Undang-Undang kepariwisataan juga dilakukan secara informal kepada pelaksana kebijakan dengan bertemu secara langsung setiap saat.

Proses penyampaian informasi implementasi kebijakan kepariwisataan selain disampaikan kepada pegawai internal Dinas Pariwisata, juga disampaikan kepada pemerintah desa, yang dilakukan dengan cara secara langsung orang dinas datang ke desa atau kelurahan, dan orang desa diundang ke Dinas Pariwisata, dalam proses komunikasi dengan pemerintah desa ini, Dinas Pariwisata juga sekaligus melakukan monitoring dan evaluasi terhadap pengembangan pariwisata. Komunikasi tentang penyampaian informasi mengenai implementasi kebijakan Undang-Undang Kepariwisataan juga dilakukan kepada Kelompok Sadar Wisata (Pokdarwis) yang ada disetiap kelurahan dan desa di Kota Batu. Komunikasi dengan Pokdarwis dilakukan melalui beberapa cara seperti mengadakan forum lalu mengundang Pokdarwis, pegawai dinas langsung berkoordinasi dengan Pokdarwis secara informal, dan juga melakukan komunikasi melalui forum Pokdarwis. Proses komunikasi dengan Pokdarwis dilakukan secara isidentil yang artinya dilakukan kapan saja apabila dibutuhkan.

Komunikasi tentang kebijakan kepariwisataan juga dilakukan kepada kelompok sasaran, yang dalam hal ini adalah pelaku wisata. Seperti yang sudah dilakukan Dinas Pariwisata melakukan komunikasi dengan para pelaku wisata hotel dan restoran di Kota Batu, yang dilakukan di hotel dengan penyampaian informasi tentang sertifikasi. Penyampain informasi mengenai implementasi kebijakan kepariwisataan juga dilakukan kepada masyarakat Kota Batu, komunikasi tersebut dilakukan Dinas Pariwisata melalui Pokdarwis di setiap desa dan kelurahan dan melalui Pusat Informasi Pariwisata (PIP) yang dibentuk oleh Dinas Pariwisata. Komunikasi kepada masyarakat dilakukan secara isidentil atau setiap saat dan setiap waktu, sesuai dengan kebutuhan. Berdasarkan data dilapangan tersebut dapat disimpulkan bahwa dalam proses implementasi kebijakan kepariwisataan, komunikasi dilakukan sudah sesuai dengan dimensi transisi menurut Edward III, dimana komunikasi dilakukan tidak hanya kepada pelaksana kebijakan, tetapi juga kepada pihak yang terkait dan kelompok sasaran. Yang dalam hal ini pegawai Dinas Pariwisata, aparatur desa, pokdarwis dan pelaku wisata atau masyarakat di Kota Batu.

Dimensi kedua dalam komunikasi adalah dimensi kejelasan. Dimensi kejelasan menurut Edward III menghendaki komunikasi yang dilakukan kepada pelaksana kebijakan, pihak lain yang berkepentingan, dan kelompok sasaran dilakukan secara jelas, sehingga pelaksana kebijakan, pihak lain yang berkepentingan dan kelompok sasaran memahami apa yang harus dipersiapkan dan dilakukan agar tujuan dari kebijakan dapat tercapai, karena setiap aktor tersebut mengetahui apa yang menjadi maksud, tujuan, sasaran, serta substansi dari kebijakan tersebut. Berdasarkan data dilapangan, proses komunikasi yang di lakukan dalam implemtasi kebijakan kepariwisataan sudah jelas, hal ini dapat tercermin dari tindakan inisiatif dari setiap bidang di Dinas Pariwisata untuk berkomunikasi dengan pihak terkait dan dalam pengembangan pariwisata di Kota Batu. Selain itu juga tercermin dari Pokdarwis yang membuat forum pertemuan di setiap bulan untuk membicarakan permasalahan di desa dan kelurahan masing-masing dan mencari solusi dari permasalahan itu. Pokdarwis juga secara aktif melakukan komunikasi dan koordinasi dengan dinas dan masyarakat untuk mengembangkan pariwisata di desa dan kelurahan masing-masing.

Kejelasan komunikasi yang dilakukan dalam proses implementasi kebijakan kepariwisataan, membuat para pelaksana, pihak yang terkait dan sasaran kebijakan memahami apa yang harus dilakukan. hal tersebut tergambarkan dari kebijakan yang diambil oleh Pokdarwis di Desa Punten dan masyarakat pengelola kampung kungkuk dengan tidak melibatkan investor dalam pengembangan kampung wisata kungkuk. Hal tersebut dilakukan mengingat dalam penyelenggaraan pariwisata masyarakat harus merasakan hasil dari pariwisata tersebut dan dapat meningkatkan kesejahteraan masyarakat, dengan keputusan tidak melibatkan investor dalam pengembangan kampung kungkuk, sehingga masyarakat 
bisa menikmati hasil dari kampung wisatanya, dan tidak menjadi tamu di kampung sendiri. Selain tanpa melibatkan investor, kebijakan yang menggambarkan kejelasan dalam proses komunikasi adalah kebijakan melakukan kerjasama dengan beberapa hotel untuk mengembangkan kampung kungkun, dan juga membrandingkan kampung kungkuk sebagai icon Desa Punten, tetapi tetap memperhatikan keseimbangan di dusun lain, dengan menjadikan dusun lain menjadi penyangga kampung wisata kungkuk. Kejelasan komunikasi kepada pelaku usaha juga tergambarkan dari setelah dilakukannya sosialisasi sertifikasi kepada pelaku wisata hotel dan restoran, para pelaku wisata hotel dan restoren sebanyak 22 pelaku mau mengajukan sertifikasi

Dimensi yang ketiga dalam komunikasi adalah dimensi konsistensi, dimensi ini menginginkan bahwa kebijakan yang diambil harus konsisten atau tidak simpang siur, sehingga pelaksana, pihak yang terkait, dan kelompok sasaran tidak mengalami kebingungan. Berdasarkan data dilapangan bahwa komunikasi yang dilakukan masih konsisten, hal tersebut tergambarkan dari kegiatan-kegiatan dalam pariwisata tidak keluar dari kebijakan Undang-Undang nomor 10 tahun 2009 tentang kepariwisataan. Selain itu juga tergambarkan dari program atau kegiatan-kegiatan yang dilakukan tetap mengarah kepada pengembangan pariwisata dan memaksimalkan potensi yang ada di Kota Batu, yang didukung dengan para pegawai dari pemerintah Kota Batu yang banyak terlibat dalam proses pengembangan pariwisata.

\section{Sumber Daya}

\section{a. Sumber Daya Manusia}

Menurut Edward III sumber daya manusia merupakan salah satu variabel yang mempengaruhi keberhasilan dari implementasi kebijakan. Sumber daya manusia yang tersedia di Kota Batu untuk mengimplementasikan kebijakan Undang-Undang Nomor 10 Tahun 2009 tentang Kepariwisataan, khusunya di Dinas Pariwisata Kota Batu masih terdapat permasalahan, dikarenakan masih terdapat pegawai yang lulusan Sekolah Menengah Atas, dan di dinas sendiri belum ada pemberdayaan untuk internal dinas. Selain itu sumber daya yang tersedia di Dinas Pariwisata dilihat dari gelar pendidikan formalnya, masih banyak pegawai yang bidang keilmuannya bukan keilmuan pariwisata, sehingga ini berdampak pada beberapa pelaksanaan program Dinas Pariwisata harus menggunakan pihak ketiga yang sudah professional di bidangnya untuk menjadi fasilitator atau pemateri.

Masih kurangnya sumber daya manusia di Dinas Pariwisata juga terlihat saat proses perumusan kebijakan, yang dimana dalam proses perencanaan dan kajian yang sifatnya berat dan teknis seperti yang dicontohkan pembuatan jalibar, Dinas Pariwisata menjalin kerjasama dengan pihak ketiga seperti akademisi dan konsultan. Hal tersebut dilakukan karena belum ada sumber daya manusia di setiap bidang yang memang dikhususkan untuk hal tersebut. Kesiapan sumber daya manusia dalam implementasi Undang-Undang Nomor 10 tahun 2009 tentang kepariwisataan tidak hanya pada Dinas Pariwisata, tetapi juga pihak lain yang terlibat, dalam hal ini ada Pusat Informasi Pariwisata yang bertugas menjadi perantara anatara Dinas dan masyarakat serta bertugas menjadi pemandu wisata kepada wisatawan yang membutuhkan. Tetapi sumber daya manusia di PIP yang jumlahnya 25 orang semuanya belum mempunyai lisensi guide, dalam upaya hal tersebut, Dinas Pariwisata memberikan pelatihan kepada PIP secara bergiliran. Selain PIP, sumber daya maunia di Pokdarwis dan masyarakat juga perlu menjadi perhatian. Untuk meningkatkan kinerja pokdarwis dan para pelaku usaha atau masyarakat, Dinas Pariwisata membuat program untuk pelatihan. Namun pelatihan pemandu untuk Pokdarwis, dilakukan masih belum menyeluruh, hanya perwakilan satu orang di setiap kecataman.

\section{b. Sumber Daya Anggaran}

Menurut Edward III keterbatasan anggaran, akan menyebabkan rendahnya keberhasilan dalam implementasi kebijakan, selain itu juga akan menyebabkan program tidak berjalan secara optimal dan disposisi para pelaku kebijakan rendah. Dinas Pariwisata sudah terdapat anggaran yang mencukupi untuk melaksanakan sebuah kebijakan, karena sistem anggaran dana yang digunakan dalam pemerintah Kota Batu adalah anggaran berbasis kinerja, jadi anggaran disesuaikan dengan kebutuhan setiap instansi. Tidak hanya di Dinas Pariwisata, dalam pengembangan kampung wisata di Kota Batu juga dibutuhkan sumber daya anggaran dari pihak yang terkait seperti pemerintah desa. Di Desa Punten dalam menunjang implementasi kebijakan kepariwisataan belum terdapat alokasi anggaran khusus untuk pengembangan pariwisata dam anggaran dana Desa Punten masih difokuskan untuk pembangunan sarana prasarana dan infrastruktur, hal tersebut sebabkan oleh terbatasnya ketersediaan dana yang ada di pemerintah Desa Punten, seperti yang sudah digambarkan di penyajian data.

Selain anggaran dana di pemerintah desa, anggaran dana di Pokdarwis juga dibutuhkan, karena Pokdarwis juga sebagai pelaksana kebijakan kepariwisataan. Namun realita dilapangan anggaran dana di Pokdarwis di Kota Batu sangat terbatas, dikarenakan dana untuk operasional berasal dari swadaya anggota dan Pokdarwis juga belum pernah mendapatkan anggaran dana dari Pemerintah Kota Batu. Seharusnya Pokdarwis di setiap desa dan kelurahan mendapatkan alokasi dana untuk operasional dari Pemerintah Kota Batu, karena Pokdarwis dibentuk dan disahkan oleh pemerintah Kota Batu.

\section{c. Sumber Daya Peralatan}

Sumber daya peralatan menurut Edward III ialah sarana prasarana yang bisa digunakan untuk operasionalisasi implementasi kebijakan, sarana prasarana tersebut meliputi tanah, gedung, dan segala sarana yang menunjang dalam implementasi kebijakan. Berdasarkan data dilapangan di Pemerintah Kota Batu dan khusunya 
Dinas Pariwisata sudah tersedia sarana prasarana seperti gedung pertemuan, gedung among tani dan kendaraan bermotor yang bisa digunakan untuk menunjang implementasi kebijakan kepariwisataan.

\section{d. Sumber Daya Kewenangan}

Menurut Edward III sumber daya kewenangan merupakan sumber daya yang penting, yang bisa mempengaruhi keberhasilan dalam implementasi kebijakan. Oleh sebab itu pelaksana dalam kebijakan yang dikeluarkan harus diberi wewenang yang cukup, sehingga bisa membuat keputusan sendiri apabila terjadi permasalahan yang harus segera diselesaikan dalam melaksanakan kebijakan yang menjadi kewenangannya. Berdasarkan data dilapangan di Dinas Pariwisata setiap bidang diberikan kewenangan yang cukup untuk mengambil keputusan apabila terdapat permasalahan yang harus segera diselesaikan dalam implementasi kebijakan kepariwisataan. Jadi apabila ada permasalahan di masyarakat setiap bidang di Dinas Pariwisata diperbolehkan berinisiatif langsung bertindak, sesuai dengan tugas dan fungsi yang melekat disetiap bidang.

Kewenangan juga diberikan kepada Pokdarwis di setiap desa dan kelurahan di Kota Batu. Pokdarwis juga mempunyai wewenang cukup untuk mengambil keputusan dalam pengembangan kampung wisata di desanya. Seperti keputusan yang sudah diambil di Desa Punten yaitu pemberlakuan sistem wisata kungkuk menjadi icon Desa Punten dan dusun lain menjadi penyangga. Masyarakat sendiri selaku pelaku wisata juga diberikan wewenang yang cukup untuk mengambil keputusan terhadap pengelolaan kampung wisata. Kewenangan pengembangan kampung wisata kungkuk seluruhnya diserahkan kepada masyarakat, dinas dan pemerintah desa berperan sebagai pembina.

\section{Struktur Birokrasi}

Struktur birokrasi merupakan aspek penting dalam implementasi kebijakan publik. Struktur birokrasi berkaitan dengan instrumen dalam menangani keperluankeperluan publik. Struktur birokrasi menjadi kunci penting dalam efektivitas dari implementasi kebijakan publik. Seringkali sumber - sumber untuk mengimplementasikan suatu kebijakan sudah cukup dan para implementator mengetahui apa dan bagaimana cara melakukannya, memiliki keinginan untuk melakukannya namun bisa jadi implementasi kebijakan publik masih belum berjalan efektif karena ketidakefisienan birokrasi.

Berdasarkan hasil penelitian yang dilakukan pada Kota Batu secara keseluruhan implementasi kebijakan pengembangan pariwisata diselenggarakan oleh birokrai multilevel yang mencakup top level yaitu pemerintah Kota Batu yang diwakili dinas terkait yakni Dinas Pariwisata. selanjutnya pada middle level terdapat Pemerintah Kecamatan Bumiaji dan buttom level terdapat Pemerintah Desa Punten.
Sebagai top level, birokrasi Dinas Pariwisata distrukturkan menjadi empat bidang yang masing-masing bertugas untuk mencapai misi yang telah ditetapkan oleh Dinas Pariwisata baik melalui program kerja yang telah ditetakan sesuai tahun anggaran maupun melalui inisiasi program swadaya dari bidang maupun yang diperoleh melalui jarring aspirasi dengan masyarakat.. Adapun visi dan misi Dinas Pariwisata secara linier juga disesuaikan dengan visi misi Kota Batu dalam bidang terkait yakni bidang pariwisata. Mengingat implementasi kebijakan wisata mencakup multilevel pemerintahan, maka alur koordinasi juga dilakukan secara hierarkis mulai dari dinas, kecamatan, desa hingga kampung wisata. Namun tidak hanya berpaku pada hierarki top down, koordinasi juga dilakukan secara lintas level misalnya dari dinas langsung dengan pokdarwis desa ataupun sebaliknya pemerintah desa juga dapat berkoordinasi dengan pokdarwis tanpa melalui dinas terlebih dahulu. Sementara itu terkait dengan pembagian kewenangan, sebagi top level dinas pariwisata menyelenggarakan fungsi pembinaan dan koordinator utama kebijakan. Sementara untuk pemerintah kecamatan lebih memegang peran koordinator dari forum pokdarwis kecamatan. Sementara itu desa sebagai bottom level lebih banyak diposisikan sebagai mitra dinas dan pokdarwis dalam menggerakkan potensi wisata desa.

Menelaah secara teoritis, Edward III dalam Widodo (2010:106) menyebutkan bahwa struktur birokrasi dalam implementasi kebijakan mencakup aspek seperti struktur organisasi serta pembagian kewenangan dan hubungan antar unit-unit kerja dalam implementasi kebijakan. Pertama terkait dengan struktur organisasi dan tata kerja pada dinas pariwisata yang dibagi menjadi empat bidang disesuaikan dengan misi dinas yang terbagi menjadi empat pula sehingga setiap misi dapat diturunkan pada masing-masing bidang yang kemudian dirumuskan ke dalam program dan kegiatan teknis. Namun disamping program yang telah ditetapkan sesuai dokumen perencanaan, pada beberapa bidang dimungkinkan adanya program swadaya yang menjadi inisiasi untuk lebih mengoptimalkan pengembangan wisata. Hal tersebut merupakan sebuah langkah positif yang dimunculkan Dinas Pariwisata karena kinerja yang dilakukan terpaku pada program kerja yang sudah ada, namun masih memungkinkan munculnya langkah-langkah inisiatif apabila dirasa dapat berkontribusi mendukung keberhasilan program lainnya.

Selanjutnya terkait dengan pembagian kewenangan, Edward III menyebutkan bahwa dalam struktur birokrasi juga memuat karakteristik fragmnentasi yang mengandung arti bahwa implementasi mengandung konsekuansi penyebaran tanggung jawab suatu kebijakan 
kepada beberapa badan yang berbeda sehingga diperlukan koordinasi. Terkait hal tersebut, implementasi kebijakan pengembangan pariwisata terfragmentasi pada beberapa level pemerintahan seperti yang telah dijelaskan sebelumnya yakni pada tingkat atas yaitu dinas, kecamatan dan pemerintah desa. Pembagian tanggung jawab yang melibatkan banyak pihak memungkinkan terjadinya distorsi kebijakan. Distorsi kewenangan diantisipasi oleh dinas dengan menjalin koordinasi intensif terutama dengan pemerintah desa dan pokdarwis. Adapun pemerintah kecamatan dalam hal ini tidak telalu memegang peran yang besar dikarenakan koordinasi yang lebih dioptimalkan oleh dinas adalah langsung kepada desa dan pokdarwis. Akan tetapi tidak hanya berlaku dari atas ke bawah, dalam hal ini pokdarwis sebagi lembaga yang terpisah dari desa juga dapat melakukan koordinasi dengan dinas tanpa melalui desa. Secara keseluruhan dalam struktur birokrasi dalam implementasi kebijakan pengembangan wisata menunjukkan sifat yang lebih fleksibel mengingat laur koordinasi tidak senantiasa dilakukan secara hierarkhis akan tetapi juga dapat bersifat lintas level.

\section{Disposisi}

Faktor disposisi atau kemauan aparatur adalah stimulus internal bagi aparatur untuk mau bersungguhsungguh dalam menjalankan kebijakan. Berbicara terkait dengan disposisi, para aparatur pemerintah seringkali dihadapkan pada kewajiban untuk mencapai target kinerja yang telah ditetapkan. Namun lebih daripada itu, seorang aparatur dituntut tidak hanya berkerja dengan berdasar pada orientasi pencapaian target namun juga menginternalisasikan jiwa pengabdian serta bekerja stulus hati kepada masyarakat. Oleh sebab itu, adanya hasrat untuk bekerja secara sungguh-sungguh menjadi penunjang utama dalam menciptakan totalitas dan profesionalitas kerja. Secara keseluruhan aparatur yang benar-benar memiliki hasrat untuk mengabdi dan melayani masyarakat akan menjadi motor bagi keberhasilan kebijakan pemerintah.

Komitmen menjadi tolak ukur utama pada aspek disposisi pada implementasi kebijakan. Dinas Pariwisata selaku leading sector dalam kebijakan pengembangan pariwisata berusaha untuk mewujudkan komitmen melalui optimalisasi pengembangan destinasi wisata. Langkah konkret yang dilakukan adalah dengan menjadikan pengembangan desa wisata sebagi program prioritas pada Renja 2018, dengan demikian Pariwisata berkoordinasi dengan OPD lain seperti Dinas Pekerjaan Umum dan Bina Marga untuk memperbaiki insfrastruktur dan menambah fasilitas wisata seperti contohnya di kampung kungkuk. Dinas juga memberikan pembinaan bersama dengan desa untuk memberdayakan masyarakat kampung kungkuk.
Selain menjalankan program yang sudah ditetapkan komitmen dinas untuk mengoptimalkan kebijakan pengembangan wisata, dinas melalui bidang pengembangan produk pariwisata juga menginisiasi kegiatan swadaya untuk mengeksplorasi destinasi wisata baru.

Sementara itu terkait dengan komitmen dinas dalam menjalankan program secara berkelanjutan masih belum begitu dirasakan masyarakat utamanya pada masyarakat kampung kungkuk. Berdasarkan penuturan yang disampaikan oleh pengelola kampung wisata kungkuk, program maupun kegiatan yang diturunkan dari dinas terutama yang bersifat pemberdayaan masih belum dirasakan efek keberlanjutannya. Hal tersebut disebabkan kurangnya monitoring serta kajian evaluasi kegiatan terkait. Terlebih adanya perombakan pegawai pada tubuh dinas seringkali mempengaruhi keberlanjutan dari program yang dilaksanakan, dalam artian mutasi pegawai terkadang membuat kegiatan yang sudah berjalan terhenti dan kemudian diganti dengan kegiatan yang baru.

Seperti yang telah dibahas sebelumnya disposisi menyangkut tentang kemauan, keinginan dan kecenderungan para pelaku kebijakan untuk melaksanakan kebijakan secar sungguh-sungguh seghingga apa yang menjadi tujuan kebijakan dapat tercapai dengan baik. Edward III dalam Widodo (2010:104) mengatakan bahwa apabila implementasi kebijakan ingin berhasil secara efektif dan efisien maka pelaksana kebijakan tidak cukup hanya mengetahui apa yang harus dilakukan tetapi juga harus memiliki kemauan untuk melaksanakan kebijakan tersebut. Edward III menyoroti bahwa setiap pegawai yang ditempatkan dalam jabatan tertentu harus memiliki dedikasi pada kebijakan yang telah ditempatkan. Terkait hal tersebut dinas pariwisata melalui kepala bidang pengembangan produk wisata telah menunjukkan komitmen dan dedikasi untuk melaksanakan kebijakan pengembangan wisata hal tersebut salah satunya terlihat dari adanya inisiasi membuat kegiatan swadaya diluar program kerja.

Inisiasi kegiatan yang dijalankan bidang pengembangan produk dinas pariwisata menjadi wujud optimalisasi kinerja aparatur dinas untuk tidak hanya bekerja berdasarkan program kerja namun juga turut mengupayakan inovasi kegiatan demi memaksimalkan keberhasilan kebijakan. Akan tetapi yang perlu dioptimalkan adalah komitmen dalam menyelenggarakan program yang berbasis pemberdayaan secara berkelanjutan. Bagaimanapun juga basis pengembangan model desa wisata menjadikan pemberdayaan masyarakat sebagai sentral dari keberhasilan program. Tidak lagi hanya berbicara soal komitmen pada tataran individu setiap aparat birokrat, namun keberhasilan kebijakan seharusnya menjadi komitmen institusi yang menjiwai 
semnagat seluruh pegawai dinas untuk bersama menyukseskan kebijakan tersebut. Terlepas dari adanya perombakan atau mutasi pegawai seharusnya tidak menjadi alasan bagi terhentinya suatu program. Setiap kebijakan yang diwujudkan melalui program pemberdayaan sudah semestinya dijalankan secara berkelanjutan sehingga sepanjang pelaksanaan kegiatan harus disertai dengan monitoring dan evaluasi untuk mengukur sejauh mana keberhasilan capaiannya. Hal tersebut yang masih menjadi koreksi bagi Dinas Pariwisata Batu untuk memberikan semangat dedikasi serta kinerja yang sungguh-sungguh dalam mengimplementasikan kebijakan yang bersifat sustainable.

\section{PENUTUP}

\section{Simpulan}

Berdasarkan penelitian dan analisis yang dilakukan dapat ditarik kesimpulan sebagai berikut: 1) Komunikasi yang dilakukan dalam implementasi kebijakan kepariwisataan, sudah memenuhi dimensi transisi, yang berarti kemunikasikan dilakukan tidak hanya kepada pelaku utama kebijakan, tetapi juga pihak yang terlibat dan kelompok sasaran, yang dalam hal ini adalah Dinas Pariwisata, Pusat Informasi Pariwisata, Apratur Desa Punten, Kelompok Sadar Wisata dan pelaku wisata atau masyarakat. Selain itu komunikasi yang dilakukan sudah memenuhi dimensi kejelasan, hal tersebut terlihat dari Dinas Pariwisata, Pemerintah Desa, Pokdarwis dan kelompok masyarakat yang sudah memahami apa yang harus dipersiapkan dan dilakukan. 2) Sumber daya disini dibagi menjadi 4 (empat) sumber daya manusia, anggaran, peralatan, dan kewenangan. Aspek sumber daya manusia dalam implementasi kebijakan pariwisata masih perlu ditingkatkan mengingat masih ada pegawai Dinas Pariwisata yang berpendidikan Sekolah Menengah Atas dan ada pegawai yang tidak sesuai dengan kompetensi pendidikan formalnya. 3) Pada aspek struktur birokrasi, implementasi kebijakan pengembangan wisata khususnya pada wisata kampung kungkuk melibatkan multilevel stakeholder yang terdiri dari pemerintah Kota melalui dinas terkait yaitu dinas pariwisata Kota Batu yang memegang kewenangan sebagai leading sector. 4) Pada aspek disposisi, komitmen dinas ditunjukkan dengan optimalisasi pelakasanaan kegiatan melalui fasilitasi sarana prasarana, pelatihan dan pembinaan serta menginisiasi kegiatan swadaya diluar program kerja sebagai upaya untuk mendukung keberhasilan program kerja yang ada. Sementara itu yang masih menjadi kekurangan dinas dalam melakasanakan kebijakan pengembangan pariwisata adalah terkait dengan komitmen untuk menciptakan sebuah program atau kegiatan yang berkelanjutan. Hal tersebut masih menjadi kritik masyarakat yang menilai bahwa pemerintah kurang bersungguh-sungguh dalam menyelenggarakan program yang berkelanjutan karena program yang telah dijalankan belum dimonitoring secara baik, sehingga hasilnya belum begitu dapat dirasakan oleh masyarakat.

\section{Saran}

Adapun saran yang dapat dipertimbangkan untuk memperbaiki implementasi kebijakat tersebut adalah sebagai berikut:1) Pembentukan mekanisme dan alur komunikasi melalui jaringan formal sehingga semua pihak dapat dengan mudah berkoordinasi; 2) Sumber daya yang perlu untuk ditingkatkan adalah sumber daya manusia pada Dinas Pariwisata agar sesuai dengan kompetensi pariwisata, serta optimalisasi peran pelatihan terhadap pokdarwis di desa; 3) Diperlukan stuktur birokrasi yang lebih jelas untuk mengatur kewenangan desa, kelurahan dan dinas pariwisata sehingga tidak terjadi overlapping kewenangan; 4) Aspek disposisi kebijakan perlu dilakukan secara berkelanjutan yang menerapkan sistem komitmen multiyear agar kepercayaan pemerintah desa terhadap Dinas Pariwisata lebih baik lagi; 5) Diperlukan analisa leverage factor yang lebih tepat dalam kebijakan pariwisata agar dapat meningkatkan dampak yang dihasilkan dari implementasi kebijakan tersebut; 6) Memperluas jangkauan UMKM yang dapat dibina untuk mendukung kebijakan pariwisata agar UMKM yang terlibat lebih banyak lagi.

\section{DAFTAR PUSTAKA}

BPS Kota Batu. 2017. Statistik Kota Batu 2017.

Arikunto S, 2006. Prosedur Penelitian Suatu Pendekatan Praktik, Ed Revisi VI, Penerbit PT Rineka Cipta, Jakarta.

Miles, Metthew B, A. Michael Huberman and Johnny Saldana. 2014. Qualitative Data Analysis, A Methods Sourcebook, Third Edition.Sage Publications, Inc.

Nugroho, Riant. 2014. Public policy, teori, manajemen, dinamika, analisis, konvergensi, dan kimia kebijakan. Edisi kelima, revisi. Gramedia: Jakarta

Sugiyono. 2008. Memahami Penelitian Kualitatif. CV Alfabeta: Bandung

Widodo, Joko.2010. Analisis Kebijakan Publik. Malang: Bayumedia. 